\title{
Computed tomography analysis of concomitance of concha bullosa, septal deviation and maxillary sinusitis
}

\author{
Konka bülloza, septum deviasyonu ve maksiller sinüzit birlikteliğinin \\ bilgisayarl tomografi analizi
}

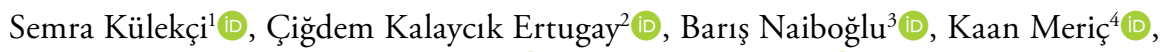 \\ Ebru Doğaner ${ }^{4} \mathbb{B}$, Shahrouz Sheideai ${ }^{3} \mathbb{D}$
}

\begin{abstract}
${ }^{1}$ Department of Otolaryngology, University of Health Sciences Fatih Sultan Mehmet Training and Research Hospital, Istanbul, Turkey
${ }^{2}$ Department of Otolaryngology, University of Health Sciences Istanbul Training and Research Hospital, Istanbul, Turkey

${ }^{3}$ Department of Otolaryngology, University of Health Sciences Haydarpaşa Numune Training and Research Hospital, Istanbul, Turkey

${ }^{4}$ Department of Radiology, University of Health Sciences Haydarpaşa Numune Training and Research Hospital, Istanbul, Turkey
\end{abstract}

\section{ABSTRACT}

Objectives: This study aims to investigate the association of concha bullosa (CB), nasal septal deviation (NSD), and maxillary sinusitis using paranasal sinus computed tomography (CT).

Patients and Methods: We retrospectively reviewed the paranasal sinus CT findings of 205 patients ( 86 males, 119 females; mean age $38.2 \pm 14.7$ years; range, $10-85$ years) referred to the department of radiology. We performed CT to patients with possible complaints related to the sinonasal region. Patients with a history of nasal and/or paranasal surgery were excluded from the study. Coronal CT sections were examined for CB, NSD, mucosal thickening (MT) of maxillary sinus and maxillary sinus ostium.

Results: There was a strong association between unilateral CB and contralateral NSD $(\mathrm{p}=0.02)$. There was no statistically significant association between MT and NSD ( $\mathrm{p}=0.18)$. There was no significant association between MT, CB and NSD in terms of their sides. There was no association between MT and the width of maxillary sinus ostium.

Conclusion: Our study findings showed that $\mathrm{CB}$ was associated with contralateral NSD. Thus paranasal CT might be needed in patients with NSD before nasal septal surgery to investigate the presence of CB.

Keywords: Computed tomography, concha bullosa, septal deviation, sinusitis.
$\ddot{O} Z$

Amaç: Bu çalışmada paranazal sinüs bilgisayarlı tomografi (BT) kullanılarak konka bülloza (KB), nazal septum deviasyonu (NSD) ve maksiller sinüzitin ilişkisi araştırıldı.

Hastalar ve Yöntemler: Radyoloji bölümüne sevk edilen 205 hastanın (86 erkek, 119 kadın; ort. yaş 38.2 \pm 14.7 yıl; dağılım, 10-85 yıl) paranazal sinüs BT bulguları retrospektif olarak incelendi. Sinonazal bölgeyle ilgili olası yakınması olan hastalara BT uygulandı. Nazal ve/veya paranazal cerrahi öyküsü olan hastalar çalışma dışı bırakıldı. Koronal BT kesitleri $\mathrm{KB}$, NSD, maksiller sinüsteki mukozal kalınlaşma $(\mathrm{MK})$ ve maksiller sinüs ostiumu açısından incelendi.

Bulgular: Tek taraflı KB ve kontralateral NSD arasında güçlü ilişki vardı $(\mathrm{p}=0.02)$. Mukozal kalınlaşma ve NSD arasında istatistiksel olarak anlamlı ilişki yoktu ( $\mathrm{p}=0.18)$. Mukozal kalınlaşma, KB ve NSD arasında tarafları açısından anlamlı ilişki yoktu. Mukozal kalınlaşma ve maksiller sinüs ostium genişliği arasında ilişki yoktu.

Sonuç: Çalışma bulgularımız KB'nin kontralateral NSD ile ilişkili olduğunu gösterdi. Buna bağlı olarak, NSD'si olan hastalarda nazal septum cerrahisi öncesi $\mathrm{KB}$ varlığını araştırmak için paranazal BT gerekli olabilir.

Anahtar sözcükler: Bilgisayarlı tomografi, konka bülloza, septum deviasyonu, sinüzit.

Received: December 23, 2018 Accepted: April 28, 2019 Published online: September 03, 2019

Correspondence: Semra Külekçi, MD. SBÜ Fatih Sultan Mehmet Eğitim ve Araştırma Hastanesi, Kulak Burun Boğaz Kliniği, 34752 Ataşehir, Istanbul, Turkey. e-mail: ercanpinar@yahoo.com

\section{Citation:}

Külekçi S, Kalaycık Ertugay Ç, Naiboğlu B, Meriç K, Doğaner E, Sheideai S. Computed tomography analysis of concomitance of concha bullosa, septal deviation and maxillary sinusitis. KBB Uygulamaları 2019;7(3):120-125. 
Nasal septal deviation (NSD) and inferior turbinate hypertrophy are frequent predisposing factors of nasal obstruction, while nasal examination can easily reveal the diagnosis. However, computed tomography (CT) is sometimes necessary to identify other sinonasal pathologies such as concha bullosa (CB), osteomeatal complex abnormalities and paranasal sinus diseases.

Concha bullosa is defined as pneumatization of middle turbinate. It is one of the most common anatomic variations of nasal cavity with incidence varying from 14 to $53 \%{ }^{[1,2]}$ The exact reason of $\mathrm{CB}$ remains unclear. ${ }^{[3]}$ Bolger et al. ${ }^{[4]}$ have classified $\mathrm{CB}$ as lamellar, bulbous and extensive according to the localization of pneumatization.

Nasal septal deviation is the convexity of septum that could narrow nasal passage together with other turbinate pathologies. The incidence of NSD ranges between 40 to $45 \% \cdot{ }^{[5]}$ Nasal septal deviation and CB might affect mucociliary activity and cause sinusoidal infections. There are some studies suggesting the coexistence of $\mathrm{CB}$ and NSD; however, the association between paranasal sinus disease and this coexistence is inconsistent and only shown in a few studies in the recent literature. ${ }^{[6-13]}$ Therefore, in this study, we aimed to investigate the association of $\mathrm{CB}, \mathrm{NSD}$, and maxillary sinusitis using paranasal sinus $\mathrm{CT}$.

\section{PATIENTS AND METHODS}

We retrospectively reviewed the radiology database to evaluate paranasal sinus CT findings of 205 patients (86 males, 119 females; mean age $38.2 \pm 14.7$ years; range, 10 to 85 years) for sinonasal abnormalities such as CB, NSD and mucosal thickening (MT) of maxillary sinuses obtained between December 2011 and June 2012 at Haydarpaşa Numune Training and Research Hospital. We used Toshiba Aquilion 64 multislice CT (Toshiba Medical Systems Co., Tokyo, Japan) to examination. Patients lay in prone position with maximum neck extension. We obtained coronal images perpendicular to the palate bone with $0.625 \mathrm{~mm}$ slice thickness. Then, sagittal and axial images with $2 \mathrm{~mm}$ slice thickness were reformatted from coronal images. We included anterior border of nasal cavity and sphenoid sinuses in our scanning area. All data were processed with bone and soft tissue algorithms. The study protocol was approved by the Haydarpaşa Numune Training and Research Hospital (2012/36) Ethics Committee. A verbal informed consent was obtained from each patient. The study was conducted in accordance with the principles of the Declaration of Helsinki.

Patient histories and clinical findings were not taken into account. Patients with a history of nasal and/or paranasal surgery were excluded from the study. The right and left sides of sinonasal region were evaluated separately. Furthermore, we also evaluated the diameter of maxillary sinus ostium that could affect drainage of maxillary sinus.

Pneumatization of middle turbinate is termed as $\mathrm{CB}$. Types of $\mathrm{CB}$ was classified as lamellar, bulbous and extensive depending on location of pneumatization. Lamellar type is pneumatization of vertical portion, bulbous type is pneumatization of bulbous segment, while pneumatization of both parts is called extensive type CB.

Direction of NSD was described according to the convexity of septal curvature. The angle between midline and the most prominent point of convexity were described as the angle of deviation. Degree of NSD was classified as mild, moderate or severe according to this angle. Mild NSD was defined as $\leq 6^{\circ}$, moderate as $6-8^{\circ}$, and severe as $\geq 8^{\circ}$. The presence of any radiographic MT above bony floor of maxillary antrum was defined as abnormal. ${ }^{[4,6]}$ We measured the maximum MT of maxillary sinus. We also measured vertical width of maxillary sinus ostium. Patients divided into two groups according to the width of maxillary sinus ostium. In group 1 ostium was larger than $5 \mathrm{~mm}$, in group 2 ostium was smaller than $5 \mathrm{~mm}$. Total of 410 ostium were measured in 205 patients. There was no correlation between MT and the width of maxillary sinus ostium $(p=0.54)$ (Table 4). All of these pathologic and anatomic elements were evaluated on the coronal section of paranasal CT scan.

\section{Statistical analysis}

Results were analyzed using the SPSS (Statistical Package for the Social Sciences) version 10.0 software (SPSS Inc., Chicago, IL, USA). Numerical values were expressed as mean \pm standard deviations, and categorical variables were expressed as percent. Arithmetic mean and median comparison of two independent samples were performed with Student's t-test or Mann-Whitney $\mathrm{U}$ tests. Chi-square tests or Fischer's exact tests were used for comparison of categorical variables. A $p$ value lower than 0.05 was considered statistically significant for all comparisons.

\section{RESULTS}

Concha bullosa was detected in 133 patients (64.9\%) and was absent in 72 patients (35.1\%). The relationship between $\mathrm{CB}$ and gender was not statistically significant $(\mathrm{p}=0.40)$. Of the $\mathrm{CB}, 26(12.7 \%)$ were located at right side and $28(13.7 \%)$ at left side while $79(38.5 \%)$ were bilateral. 


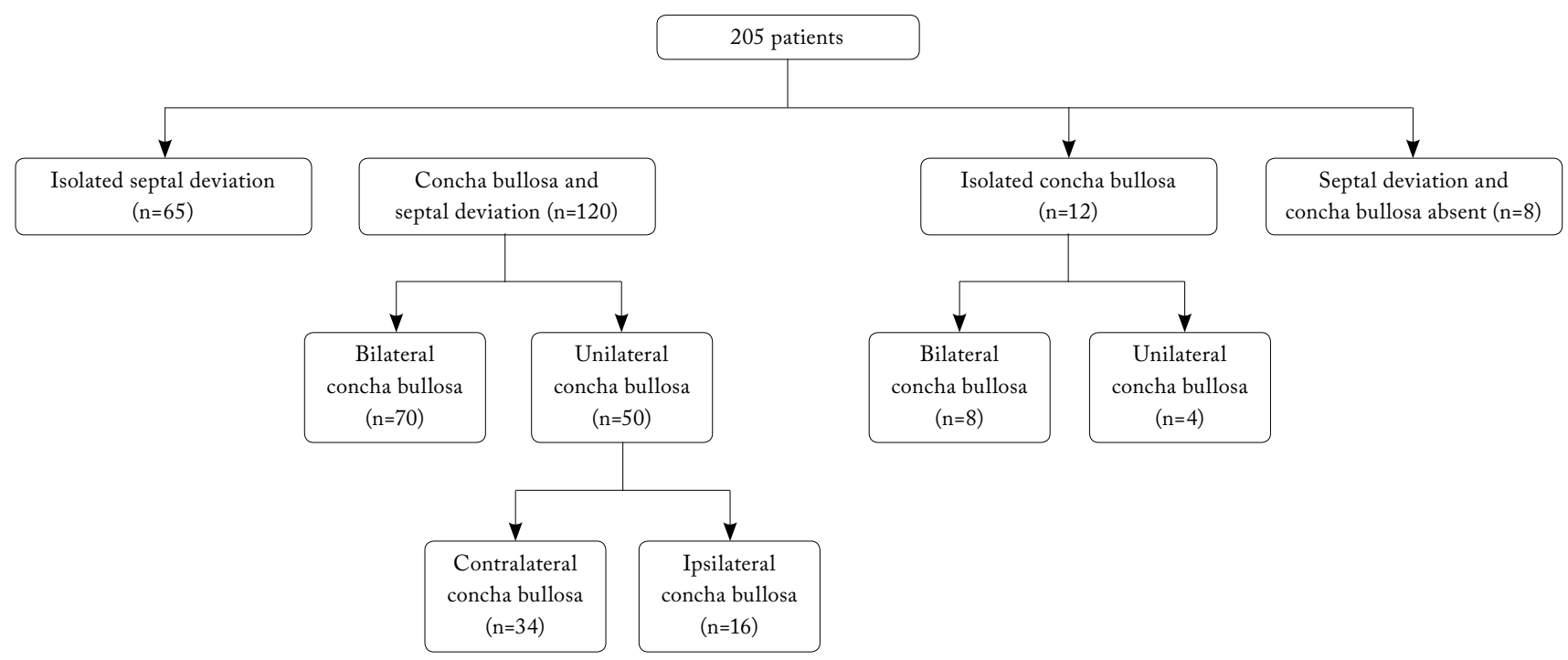

Figure 1. Distribution of concha bullosa and nasal septal deviation groups.

Of the patients, 185 (90.2\%) had NSD. There was no statistical difference between gender and presence of NSD ( $p=0.21)$. Mild NSD was found in 59 patients, moderate in 63 patients and severe in 63 patients. Mean angle of NSD was $8.06 \pm 4.42^{\circ}$ (range, $2-42^{\circ}$ ). Mild and moderate deviations were detected higher on the left side while severe deviation was higher on the right side $(\mathrm{p}=0.001)$.

Considering the localizations of $\mathrm{CB}$ and NSD, seven patients with right-sided $\mathrm{CB}$ had NSD on the same side while 17 patients had NSD on the left side. Seventeen patients with left-sided CB had NSD on the right side while nine patients had NSD on the left side. In bilateral $\mathrm{CB}$ group, 40 patients had right-sided NSD while 31 had left-sided NSD (Figures 1-3 and Table 1).

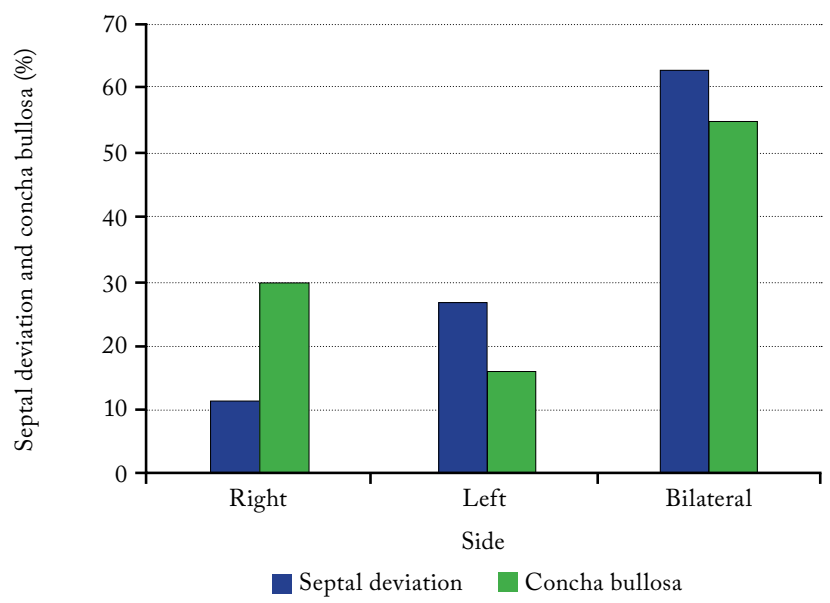

Figure 2. Localization of concha bullosa and nasal septal deviation.
There was a strong association between unilateral CB and contralateral NSD ( $\mathrm{p}=0.02)$.

Mucosal thickening was observed in 161 patients $(78.5 \%)$ and the average thickness was $14.9 \pm 1.5 \mathrm{~mm}$. MT was right sided in 22 patients, left sided in 15 patients, and bilateral in 106 patients. The relationship between MT and gender was not significant $(p=0.12)$. We examined the potential relationship between MT and NSD but we could not find any statistical significance $(p=0.18)$. Additionally, there was no association between MT and $\mathrm{CB}(\mathrm{p}=0.11)$. There was no statistically significant relationship between MT, CB and NSD in terms of their sides (Tables 2, 3).

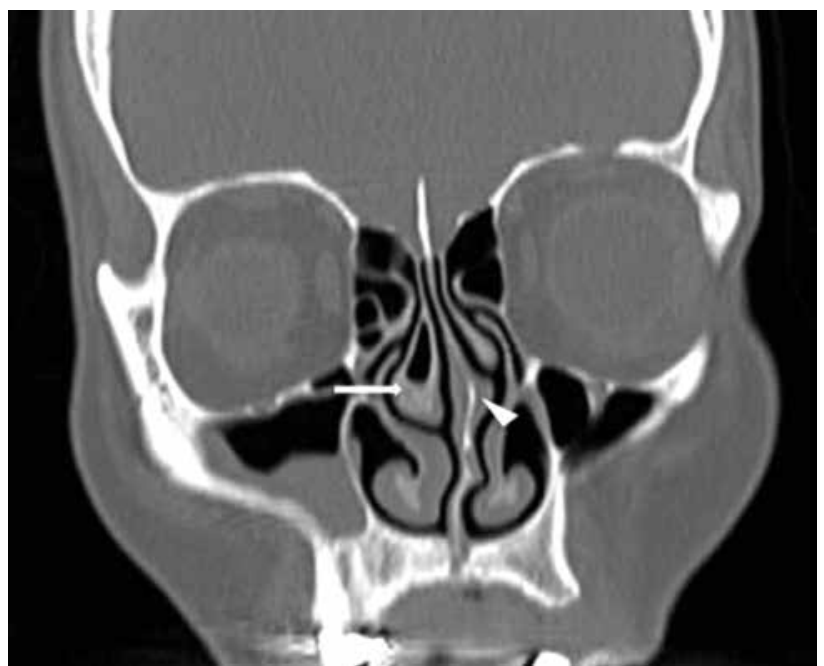

Figure 3. Coronal paranasal sinus computed tomography scan demonstrating right concha bullosa (arrow) and left nasal septal deviation (arrow head). 


\begin{tabular}{|c|c|c|c|c|c|}
\hline \multirow[b]{3}{*}{ Concha bullosa } & \multicolumn{4}{|c|}{$\begin{array}{l}\text { Table } 1 \\
\text { a bullosa and nasal septal deviation }\end{array}$} & \multirow[b]{3}{*}{$p$} \\
\hline & \multicolumn{2}{|c|}{ Right NSD } & \multicolumn{2}{|c|}{ Left NSD } & \\
\hline & $\mathrm{n}$ & $\%$ & $\mathrm{n}$ & $\%$ & \\
\hline Right & 7 & 10.9 & 17 & 29.8 & \\
\hline Left & 17 & 26.6 & 9 & 15.8 & 0.02 \\
\hline Bilateral & 40 & 62.5 & 31 & 54.4 & \\
\hline
\end{tabular}

\begin{tabular}{|c|c|c|c|}
\hline \multicolumn{4}{|c|}{$\begin{array}{c}\text { Table } 2 \\
\text { Relationship between concha bullosa, nasal septal deviation and mucosal thickening }\end{array}$} \\
\hline & Mucosal thickening (+) & Mucosal thickening (-) & \\
\hline & $\mathrm{n}$ & $\mathrm{n}$ & \\
\hline \multicolumn{4}{|c|}{ Nasal septal deviation } \\
\hline+ & 143 & 42 & \multirow{2}{*}{0.18} \\
\hline- & 18 & 2 & \\
\hline \multicolumn{4}{|c|}{ Concha bullosa } \\
\hline+ & 100 & 33 & \multirow{2}{*}{0.11} \\
\hline- & 61 & 11 & \\
\hline
\end{tabular}

\begin{tabular}{|c|c|c|c|c|}
\hline \multicolumn{5}{|c|}{$\begin{array}{c}\text { Table } 3 \\
\text { Localization of concha bullosa, nasal septal deviation and mucosal thickening }\end{array}$} \\
\hline & Right MT & Left MT & Bilateral MT & \\
\hline & $\mathrm{n}$ & $\mathrm{n}$ & $\mathrm{n}$ & \\
\hline \multicolumn{5}{|c|}{ Nasal septal deviation } \\
\hline Right & 10 & 6 & 52 & \multirow{2}{*}{0.78} \\
\hline Left & 12 & 9 & 54 & \\
\hline \multicolumn{5}{|c|}{ Concha bullosa } \\
\hline Right & 5 & 1 & 13 & \multirow{3}{*}{0.30} \\
\hline Left & 1 & 1 & 20 & \\
\hline Bilateral CB & 9 & 6 & 44 & \\
\hline
\end{tabular}

\begin{tabular}{|c|c|c|c|c|c|}
\hline \multicolumn{6}{|c|}{$\begin{array}{c}\text { Table } 4 \\
\text { Relationship between mucosal thickening and ostium width }\end{array}$} \\
\hline & \multicolumn{2}{|c|}{ Group 1} & \multicolumn{2}{|c|}{ Group 2} & \multirow[b]{2}{*}{$p$} \\
\hline & $\mathrm{n}$ & Mean \pm SD & $\mathrm{n}$ & Mean \pm SD & \\
\hline \multicolumn{6}{|c|}{ Mucosal thickening } \\
\hline Right & 162 & $6.2 \pm 5.5$ & 43 & $7 \pm 9.1$ & 0.54 \\
\hline Left & 158 & $7.4 \pm 6.8$ & 47 & $6.6 \pm 5.6$ & 0.54 \\
\hline
\end{tabular}

Patients were divided into two groups according to the width of maxillary sinus ostium. In group 1, ostium was larger than $5 \mathrm{~mm}$, while in group 2, ostium was smaller than $5 \mathrm{~mm}$. Totally 410 ostia were measured in 205 patients. There was no correlation between MT and the width of maxillary sinus ostium ( $\mathrm{p}=0.54)$ (Table 4).

\section{DISCUSSION}

Concha bullosa is one of the most frequent anatomic variations of the nasal cavity with incidence varying from 14 to $53 \% .^{[1,2]}$ In our study, the incidence was $64.9 \%$, which is higher than these reports. This may be because the authors may have used different criteria 
to define $\mathrm{CB}$. We defined $\mathrm{CB}$ as any degree of pneumatization, regardless of size or localization. Type of CB was classified as lamellar, bulbous or extensive on the location of pneumatization by using the method of Bolger et al. ${ }^{[4]}$ Our results demonstrated that extensive type of $\mathrm{CB}$ was more frequent than other types, which is similar to the study of Hatipoglu et al. ${ }^{[7]}$ Stallman et al. ${ }^{[8]}$ reported the incidence of unilateral $\mathrm{CB}$ as $23 \%$ and bilateral as $21 \%$. We detected $\mathrm{CB}$ unilaterally located in $54(26.4 \%)$ and bilaterally located in 79 (38.5\%) patients. There was a higher incidence of $\mathrm{CB}$ in females in comparison to males (60.1\%).

Nasal septal deviation is the most common disorder of the nose with an incidence varying between 40 and $65 \% \cdot{ }^{[5,8,9]}$ However, all these studies have evaluated the paranasal CT findings of patients with nasal symptoms, thus, these results do not reveal the actual incidence in normal population. For this reason, the incidence of NSD in normal population still remains unclear. In our study, 185 patients (90.2\%) had NSD and our incidence was significantly higher than other reports. The reason for this difference is most likely due to our classification of NSD. We defined it as any bending of nasal septum from the midline. However, we classified NSD according to the angle between midline and the most prominent point of convexity. Stallman et al., ${ }^{[8]}$ Yigit et al., ${ }^{[9]}$ and Hatipoglu et al. ${ }^{[10]}$ found an increased incidence of $\mathrm{CB}$ and contralateral NSD coexistence. We detected similar results with these studies. However, either the reason of this correlation or whichever occurs primarily are still unknown conditions in literature. Further radiologic and anatomical studies are needed to reveal it. Additionally, the relationship between NSD and types of CB was also investigated in some of these studies. ${ }^{[8,9]}$ In our study, we did not compare the subgroups of $\mathrm{CB}$ and NSD.

It has been suggested that $\mathrm{CB}$ can predispose to the obstruction of ostium, and can be an etiologic factor of sinusitis. ${ }^{[7,8,13]} \mathrm{We}$ measured the maximum MT of maxillary sinus by considering any significant thickening of sinus mucosa. Mucosal thickening was observed in 161 patients (78.5\%) while the relationship between MT and gender was not statistically significant.

Ünlü et al. ${ }^{[14]}$ demonstrated no relationship between $\mathrm{CB}$ and sinusitis. On the other hand, they investigated the relationship between subgroups of $\mathrm{CB}$ and sinusitis and found a correlation between the bulbous-extensive type and sinusitis. Mohebbi et al. ${ }^{[11]}$ analyzed CT of 463 patients presenting with nasal obstruction or chronic sinusitis and concluded that no clear correlation could be established between $\mathrm{CB}$ and the severity of sinusitis or between severity of sinusitis, osteomeatal involvement and the degree of septal deviation. Fadda et al. ${ }^{[12]}$ studied anatomical variations in a series of 200 patients with persistent symptoms of rhinosinusitis after failure of medical therapies and identified significant association between specific sinus disease and presence of anatomic variations as NSD and bilateral CB. Recently, Balikci et al. ${ }^{[13]}$ analyzed $296 \mathrm{CT}$ scans and showed significant relationships between $\mathrm{CB}$ and contralateral NSD, while they did not detect any significant relationships between $\mathrm{CB}$ and sinus disease or NSD and sinus disease, similar to results. Several other studies revealed no correlation between $\mathrm{CB}$ and sinusitis. ${ }^{[8,15,16]}$ In our study, there was also no association between $\mathrm{MT}$ and $\mathrm{CB}$. Also, the relationship between the side of $\mathrm{MT}$ and the side of $\mathrm{CB}$ was not statistically significant. A clinical/radiological correlation and analysis may clarify the differences between the studies and provide improvements.

Some studies have suggested a potential relationship between NSD and sinusitis. Hatipoglu et al. ${ }^{[10]}$ found significant association between the degree of NSD and the presence of sinusitis. In addition, NSD over than $3.5^{\circ}$ was suggested as a predictor of sinus pathologies in another report. ${ }^{[17]}$ Nevertheless, many authors failed to show any correlation between NSD and sinus disease. ${ }^{[18,19]}$ In concordance with these studies, the current study concluded that there was no association between these two parameters $(p=0.18)$. The relationship between the side of MT and NSD was also not statistically significant.

We also evaluated the width of maxillary sinus ostium which might have a role in maxillary mucosal changes. There was no correlation between MT and the width of maxillary sinus ostium. However, the limitation of this evaluation was that we only measured the bony part of the ostium and did not consider the mucosal part of ostium. Another limitation of our study was that we did not compare the $\mathrm{CB}$ types separately with MT.

In conclusion, $\mathrm{CB}$ was associated with contralateral NSD in our study. Therefore, paranasal CT might be needed in patients with septum deviation before nasal septal surgery to identify the presence of $\mathrm{CB}$. Although our study revealed the coexistence of $\mathrm{CB}$ and contralateral NSD, we were unable to demonstrate any association between maxillary sinus disease and CB or NSD.

\section{Declaration of conflicting interests}

The authors declared no conflicts of interest with respect to the authorship and/or publication of this article.

\section{Funding}

The authors received no financial support for the research and/or authorship of this article. 


\section{REFERENCES}

1. Lloyd GA. CT of the paranasal sinuses: study of a control series in relation to endoscopic sinus surgery. J Laryngol Otol 1990;104:477-81.

2. Lloyd GA, Lund VJ, Scadding GK. CT of the paranasal sinuses and functional endoscopic surgery: a critical analysis of 100 symptomatic patients. J Laryngol Otol 1991;105:181-5.

3. Stammberger H. Functional endoscopic sinus surgery, the messerklinger technique. Philadelphia: B.C. Decker; 1991.

4. Bolger WE, Butzin CA, Parsons DS. Paranasal sinus bony anatomic variations and mucosal abnormalities: CT analysis for endoscopic sinus surgery. Laryngoscope 1991;101:56-64.

5. Arslan H, Aydinlioğlu A, Bozkurt M, Egeli E. Anatomic variations of the paranasal sinuses: CT examination for endoscopic sinus surgery. Auris Nasus Larynx 1999;26:39-48.

6. Subramanian S, Lekhraj Rampal GR, Wong EF, Mastura $\mathrm{S}$, Razi A. Concha bullosa in chronic sinusitis. Med J Malaysia 2005;60:535-9.

7. Hatipoğlu HG, Cetin MA, Yüksel E. Concha bullosa types: their relationship with sinusitis, ostiomeatal and frontal recess disease. Diagn Interv Radiol 2005;11:145-9.

8. Stallman JS, Lobo JN, Som PM. The incidence of concha bullosa and its relationship to nasal septal deviation and paranasal sinus disease. AJNR Am J Neuroradiol 2004;25:1613-8.

9. Yiğit O, Acioğlu E, Cakir ZA, Sişman AS, Barut AY. Concha bullosa and septal deviation. Eur Arch Otorhinolaryngol 2010;267:1397-401.

10. Hatipoglu HG, Cetin MA, Yuksel E. Nasal septal deviation and concha bullosa coexistence: CT evaluation. B-ENT 2008;4:227-32.
11. Mohebbi A, Ahmadi A, Etemadi M, Safdarian M, Ghourchian S. An epidemiologic study of factors associated with nasal septum deviation by computed tomography scan: a cross sectional study. BMC Ear Nose Throat Disord 2012;12:15.

12. Fadda GL, Rosso S, Aversa S, Petrelli A, Ondolo C, Succo G. Multiparametric statistical correlations between paranasal sinus anatomic variations and chronic rhinosinusitis. Acta Otorhinolaryngol Ital 2012;32:244-51.

13. Balikci HH, Gurdal MM, Celebi S, Ozbay I, Karakas M. Relationships among concha bullosa, nasal septal deviation, and sinusitis: Retrospective analysis of 296 cases. Ear Nose Throat J 2016;95:487-491.

14. Ünlü HH, Akyar S, Caylan R, Nalça Y. Concha bullosa. J Otolaryngol 1994;23:23-7.

15. Danese M, Duvoisin B, Agrifoglio A, Cherpillod J, Krayenbuhl M. Influence of naso-sinusal anatomic variants on recurrent, persistent or chronic sinusitis. X-ray computed tomographic evaluation in 112 patients. J Radiol 1997;78:651-7. [Abstract]

16. Lam WW, Liang EY, Woo JK, Van Hasselt A, Metreweli C. The etiological role of concha bullosa in chronic sinusitis. Eur Radiol 1996;6:550-2.

17. Javadrashid R, Naderpour M, Asghari S, Fouladi DF, Ghojazadeh M. Concha bullosa, nasal septal deviation and paranasal sinusitis; a computed tomographic evaluation. B-ENT 2014;10:291-8.

18. Hamdan AL, Bizri AR, Jaber M, Hammoud D, Baino T, Fuleihan N. Nasoseptal variation in relation to sinusitis. A computerized tomographic evaluation. J Med Liban 2001;49:2-5.

19. Collet S, Bertrand B, Cornu S, Eloy P, Rombaux P. Is septal deviation a risk factor for chronic sinusitis? Review of literature. Acta Otorhinolaryngol Belg 2001;55:299-304. 